\title{
Whitlockite-Type Structure as a Matrix for Optical Materials: Synthesis and Characterization of Novel TM-SM Co-Doped Phosphate Cag $\mathrm{Gd}\left(\mathrm{PO}_{4}\right)_{7}$, a Single-Phase White Light Phosphors
}

\author{
Ivan V. Nikiforov ${ }^{1}\left(\mathbb{D}\right.$, Dina V. Deyneko ${ }^{1,2}\left(\mathbb{D}\right.$, Dmitry A. Spassky $^{3,4}$, Bogdan I. Lazoryak ${ }^{1}$ \\ and Sergey M. Aksenov $2,5, *$ (D) \\ 1 Department of Chemistry, Lomonosov Moscow State University, 119991 Moscow, Russia; \\ ivan.nikiforov@chemistry.msu.ru (I.V.N.); deynekomsu@gmail.com (D.V.D.); bilazoryaka@gmail.com (B.I.L.) \\ 2 Laboratory of Arctic Mineralogy and Material Sciences, Kola Science Centre, Russian Academy of Sciences, \\ 184209 Apatity, Russia \\ 3 Skobeltsyn Institute of Nuclear Physics, Lomonosov Moscow State University, 119991 Moscow, Russia; \\ dmitry.spasskiy@ut.ee \\ 4 Institute of Physics, University of Tartu, 50411 Tartu, Estonia \\ 5 Kola Science Centre, Geological Institute, Russian Academy of Sciences, 184209 Apatity, Russia \\ * Correspondence: aks.crys@gmail.com; Tel.: +7-8155575350
}

check for

updates

Citation: Nikiforov, I.V.; Deyneko, D.V.; Spassky, D.A.; Lazoryak, B.I.; Aksenov, S.M. Whitlockite-Type Structure as a Matrix for Optical Materials: Synthesis and Characterization of Novel TM-SM Co-Doped Phosphate $\mathrm{Ca}_{9} \mathrm{Gd}\left(\mathrm{PO}_{4}\right)_{7}$, a Single-Phase White Light Phosphors. Minerals 2022, 12, 76. https:// doi.org/10.3390/min12010076

Academic Editor: Oleg I. Siidra

Received: 19 December 2021

Accepted: 6 January 2022

Published: 9 January 2022

Publisher's Note: MDPI stays neutral with regard to jurisdictional claims in published maps and institutional affiliations.

Copyright: (c) 2022 by the authors. Licensee MDPI, Basel, Switzerland. This article is an open access article distributed under the terms and conditions of the Creative Commons Attribution (CC BY) license (https:// creativecommons.org/licenses/by/ $4.0 /)$.

\begin{abstract}
A series of novel phosphates with the general formulas $\mathrm{Ca}_{9} \mathrm{Gd}_{0.9-x} \mathrm{Tm}_{0.1} \mathrm{Sm}_{x}\left(\mathrm{PO}_{4}\right)_{7}$ and $\mathrm{Ca}_{9} \mathrm{Gd}_{0.9-y} \mathrm{Tm}_{y} \mathrm{Sm}_{0.1}\left(\mathrm{PO}_{4}\right)_{7}$ were synthesized by solid-state method. As-obtained phosphates were characterized by powder $\mathrm{X}$-ray diffraction and second harmonic generation analyses, dielectric measurements, luminescence spectroscopy. All samples were single phase and characterized by the whitlockite-type structure with space group R3c. An influence of admixture concentration of $\mathrm{REE}^{3+}$ ions in the initial host on dielectric properties was studied in details. Synthesized phosphates are characterized by intensive luminescence. The emission in the orange region of the visible spectrum is observed for $\mathrm{Ca}_{9} \mathrm{Gd}_{0.9} \mathrm{Sm}_{0.1}\left(\mathrm{PO}_{4}\right)_{7}$ with a maximum intensity band at $602 \mathrm{~nm}$. The line in blue region at $455 \mathrm{~nm}$, which corresponds to ${ }^{1} \mathrm{D}_{2} \rightarrow{ }^{3} \mathrm{~F}_{4} \mathrm{Tm}^{3+}$ transition, is registered for $\mathrm{Ca}_{9} \mathrm{Gd}_{0.9} \mathrm{Tm}_{0.1}\left(\mathrm{PO}_{4}\right)_{7}$. Emission in the white region of CIE coordinates was registered for Tm-Sm co-doped compounds.
\end{abstract}

Keywords: phosphates; luminescence spectroscopy; whitlockite-type compounds; energy transfer; cation distribution; thulium; samarium

\section{Introduction}

Inorganic oxysalts with the whitlockite-type structure [in particular, beta-tricalcium phosphate, $\beta$-Ca $\mathrm{Ca}_{3}\left(\mathrm{PO}_{4}\right)_{2}$ ] attract interest due to different physical properties [1]. In the crystal structure of pure $\beta-\mathrm{Ca}_{3}\left(\mathrm{PO}_{4}\right)_{2}$ (space group $\mathrm{R} 3 c, \mathrm{Z}=21$ ) $\mathrm{Ca}^{2+}$ ions occupy five non-equivalent $M 1-M 5$ sites [2,3]. The different types of $\mathrm{Ca}^{2+}$ substitutions by mono-, di- or trivalent cations make a significant influence on the physical properties (especially optical) [4,5] due to the local distortion of coordination environment of the central cations. Moreover, the variable occupancy of the M4 site (it can be either fully vacant or partially occupied up to half occupancy) makes it possible to change the symmetry of the crystal structure with the breaking of the symmetry center, which is important for the non-linear optical properties. The impact of cationic and anionic substitutions on luminescence properties has been studied previously in details $[4,6]$. It was shown that homo- and heterovalent substitutions occur without the change of $\beta-\mathrm{Ca}_{3}\left(\mathrm{PO}_{4}\right)_{2}$-type structure. However, in some compounds with $\beta-\mathrm{Ca}_{3}\left(\mathrm{PO}_{4}\right)_{2}$-type structure which contain cations of different oxidation states, the co-doping of admixture quantity ions is necessary to charge balance of the structure. Such doping may change physical properties and crystal structure [7].

During the last years, a number of studies were focused on heterovalent substitutions with the doping of the initial host by rare-earth elements (REE). REE ions are characterized 
by emission in the visible region, arising due to $4 f-4 f$ or $5 d-4 f$ electron transitions. The main goal of such modifications is the crystal chemical design of novel inorganic phosphors for LED applications. The materials developed using the initial $\beta-\mathrm{Ca}_{3}\left(\mathrm{PO}_{4}\right)_{2}$ host doped with $\mathrm{Tm}^{3+}$ ions can be considered as potential blue phosphors excited by UV radiation [8,9], while the $\mathrm{Sm}^{3+}$-doped phosphates show orange-red emission [10]. Moreover, the luminescent properties can be significantly improved by co-doping with other REE, such as $\mathrm{Gd}^{3+}$ [11] due to the energy transfer processes. Previously it was shown that co-doping by $\mathrm{Gd}^{3+}$ ions results in energy pump processes [11], high quantum yield [6], color tuning [12], and improving luminescence characteristics [6].

Among vanadates with the $\beta$-Ca $3\left(\mathrm{PO}_{4}\right)_{2}$-type structure, $\mathrm{Ca} 9 \mathrm{Gd}\left(\mathrm{VO}_{4}\right)_{7}$ is a good candidate as a host [13], and the influence of the co-doping by a $\mathrm{Tm}^{3+}-\mathrm{Sm}^{3+}$ pair has been recently reported [14]. However, a similar study for the phosphate analog has not been published so far, and the role of $\mathrm{Tm}^{3+}-\mathrm{Sm}^{3+}$ co-doping admixture on the crystal structure and phase transitions of $\mathrm{Ca}_{9} \mathrm{Gd}\left(\mathrm{PO}_{4}\right)_{7}$ remains unknown. Despite the isostructurality of $\mathrm{Ca}_{3}\left(\mathrm{PO}_{4}\right)_{2}$ and $\mathrm{Ca}_{3}\left(\mathrm{VO}_{4}\right)_{2}$ phosphates are characterized by better chemical and thermal stability and environmental friendliness compared to vanadates. So, phosphates are more promising compounds for phosphors than other host-matrix, as vanadate [15].

The current study represents a complex analysis of phosphates with the formulas $\mathrm{Ca}_{9} \mathrm{Gd}_{0.9-x} \mathrm{Tm}_{0.1} \mathrm{Sm}_{x}\left(\mathrm{PO}_{4}\right)_{7}$ and $\mathrm{Ca}_{9} \mathrm{Gd}_{0.9-y} \mathrm{Tm}_{y} \mathrm{Sm}_{0.1}\left(\mathrm{PO}_{4}\right)_{7}$ based on the means X-ray powder diffraction, the second harmonic generation as well as dielectric and luminescence spectroscopy.

\section{Materials and Methods}

Series of phosphates $\mathrm{Ca}_{9} \mathrm{Gd}_{0.9-x} \mathrm{Tm}_{0.1} \mathrm{Sm}_{x}\left(\mathrm{PO}_{4}\right)_{7}\left(\mathrm{Gd}_{0.9-x} \mathrm{Tm}_{0.1} \mathrm{Sm}_{x}, x=0 ; 0.1 ; 0.2 ; 0.3\right)$ and $\mathrm{Ca}_{9} \mathrm{Gd}_{0.9-y} \mathrm{Tm}_{y} \mathrm{Sm}_{0.1}\left(\mathrm{PO}_{4}\right)_{7}\left(\mathrm{Gd}_{0.9-y} \mathrm{Tm}_{y} \mathrm{Sm}_{0.1}, y=0 ; 0.1 ; 0.2 ; 0.3\right)$ were synthesized by a solid-state method in air from stoichiometric mixtures of $\mathrm{CaHPO}_{4} \cdot 2 \mathrm{H}_{2} \mathrm{O}(99.9 \%)$, $\mathrm{CaCO}_{3}(99.9 \%), \mathrm{REE}_{2} \mathrm{O}_{3}\left(\mathrm{REE}-\mathrm{Gd}^{3+}, \mathrm{Tm}^{3+}, \mathrm{Sm}^{3+}\right)(99.99 \%)$ at $1150{ }^{\circ} \mathrm{C}$ for $100 \mathrm{~h}$ with several intermediate grindings. The precursors were controlled by the powder $\mathrm{X}$-ray diffraction (PXRD) patterns, and no impurities were detected.

The PXRD patterns were collected on a Thermo ARL X'TRA powder diffractometer (Bragg-Brentano geometry, Scintillator detector, $\mathrm{CuK} \alpha$ radiation, $\lambda=1.5418 \AA$, Thermo Fisher Scientific, Waltham MA, USA). The PXRD data were collected at room temperature in the $2 \theta$ range between $5^{\circ}$ and $65^{\circ}$ with a step interval of $0.02^{\circ}$. Crystallographic SearchMatch and Jana2006 [16] programs were used to determine the unit cell parameters.

Photoluminescence emission (PL) and excitation (PLE) spectra were recorded using laboratory set-up based on a LOT-Oriel MS-257 spectrograph (L.O.T.-Oriel, Irvine, CA, USA) with a $75 \mathrm{~kW}$ xenon light source (pulse length $\tau=2 \mu \mathrm{s}$, pulse frequency $v=80 \mathrm{~Hz}$, wavelength resolution $0.5 \mathrm{~nm}$; photomultiplier tube (PMT) Hamamatsu R928). All measurements were performed at room temperature.

Dielectric permittivity $\varepsilon$ and dielectric loss tangent $\tan \delta$ in the air were measured by a double-contact method in the frequency range of 1-106 Hz at 300-1270 K (heating rate of $10 \mathrm{~K} / \mathrm{min}$ ), with the assistance of a Solartron 7081 precision voltmeter and a Solartron 1260 frequency response analyzer (Karpov Institute, Moscow, Russia). Ceramic pellets (1.5 mm-thick and 5-6 $\mathrm{mm}$ in diameter) were prepared by pressing and sintering at $1473 \mathrm{~K}$ for $12 \mathrm{~h}$. Pt paste was applied to the flat surfaces of the pellets, and then, they were heated at $1023 \mathrm{~K}$ for $4 \mathrm{~h}$ to produce platinum electrodes.

The second harmonic generation (SHG) signal was measured with a $Q$-switched YAG: Nd laser at $\lambda_{\omega}=1064 \mathrm{~nm}$ in the reflection mode (Karpov Institute, Moscow, Russia) [17].

Scanning electron microscopy (SEM) (Tescan Analytics, Fuveau, France) observations were performed using a Tescan VEGA3 scanning electron microscope. SEM images were acquired using a secondary electron (SE) imaging and backscattered electron (BSE) imaging technique. 


\section{Results and Discussion}

PXRD patterns of $\mathrm{Gd}_{0.9-x} \mathrm{Tm}_{0.1} \mathrm{Sm}_{x}$ and $\mathrm{Gd}_{0.9-y} \mathrm{Tm}_{y} \mathrm{Sm}_{0.1}$ are shown in Figure 1. The number and positions of peaks correspond to $\mathrm{Ca}_{9} \mathrm{Dy}\left(\mathrm{PO}_{4}\right)_{7}$ (PDF Card No 49-1086) for all as-synthesized solid solutions. Thus, the samples were single-phase and characterized by the whitlockite-type structure with polar space group (SG) $R 3 c$ (depending on the structural feature of compounds with $\beta-\mathrm{Ca}_{3}\left(\mathrm{PO}_{4}\right)_{2}$-type structure may also crystallize in non-polar SG $R \overline{3} c$ [18]). PXRD patterns for both SGs are almost identical, and it is rather difficult to identify them based on the powder diffraction data only [19]. However, the noncentrosymmetric structure (described by the polar SG R3c) can be confirmed by SHG measurements. The presence of a weak SHG signal response $(\approx 1-1.5$ by quartz standard) for $\mathrm{Gd}_{0.9-x} \mathrm{Tm}_{0.1} \mathrm{Sm}_{x}$ and $\mathrm{Gd}_{0.9-y} \mathrm{Tm}_{y} \mathrm{Sm}_{0.1}$ confirms that these samples are characterized by polar SG R3c (in case of the absence of SHG response the SG should be $R \overline{3} c$ [2]).

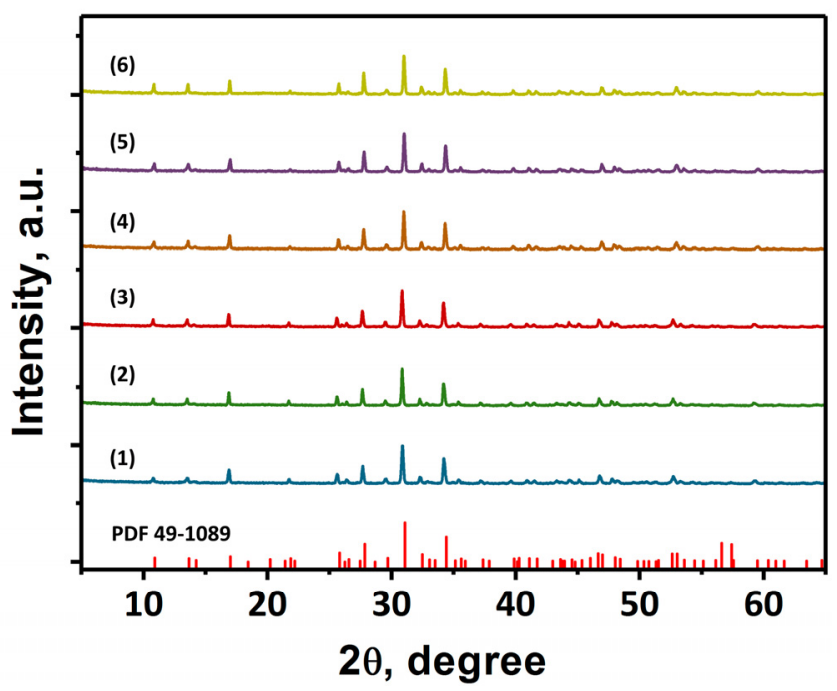

Figure 1. PXRD patterns for $\mathrm{Ca}_{9} \mathrm{Gd}_{0.9-x} \mathrm{Tm}_{0.1} \mathrm{Sm}_{x}\left(\mathrm{PO}_{4}\right)_{7}(x=0$ (1); 0.2 (2); 0.3 (3)) and $\mathrm{Ca}_{9} \mathrm{Gd}_{0.9-y} \mathrm{Tm}_{y} \mathrm{Sm}_{0.1}\left(\mathrm{PO}_{4}\right)_{7}(y=0$ (4); $0.1(5) ; 0.2(6))$ with Bragg reflections for $\mathrm{Ca}_{9} \mathrm{Dy}\left(\mathrm{PO}_{4}\right)_{7}(\mathrm{PDF}$ Card No 49-1086).

The calculated values of the unit cell volumes for $\mathrm{Gd}_{0.9-x} \mathrm{Tm}_{0.1} \mathrm{Sm}_{x}$ and $\mathrm{Gd}_{0.9-y} \mathrm{Tm}_{y} \mathrm{Sm}_{0.1}$ are given in Figure 2. In comparison with pure $\mathrm{Ca}_{9} \mathrm{Gd}\left(\mathrm{PO}_{4}\right)_{7}[20]$ the linear decrease of the unit cell volume with $\mathrm{Tm}^{3+}$ doping is observed for $\mathrm{Gd}_{0.9-y} \mathrm{Tm}_{y} \mathrm{Sm}_{0.1}$, while the increase of the unit cell volumes corresponds to $\mathrm{Sm}^{3+}$ doping of $\mathrm{Gd}_{0.9-x} \mathrm{Tm}_{0.1} \mathrm{Sm}_{x}$. Such changes of the unit cell volumes can be explained by the substitution of $\mathrm{Gd}^{3+}$ ion $\left(r_{\mathrm{VI}}=0.94 \AA\right)$ by $\mathrm{Tm}^{3+}$ $\left(r_{\mathrm{VI}}=0.88 \AA\right)$ and $\mathrm{Sm}^{3+}\left(r_{\mathrm{VI}}=0.96 \AA\right)$ with smaller and bigger ionic radius, respectively [21].

The relative ionic radius difference $\left(D_{r}\right)$ characterizes an effective substitution in the crystal structure of the initial host. The $D_{r}$ must be less than $30 \%$. The value of relative ionic radius difference can be calculated by the following equation [3]:

$$
D_{r}=\left|\frac{r_{s}-r_{d}}{r_{s}}\right| \times 100 \%,
$$

where $r_{s}$ and $r_{d}$ are ionic radii for substituted and dopant ion, respectively, with the same coordination number $(\mathrm{CN})$. The obtained $D_{r}$ values are given in Table 1 and do not exceed $30 \%$. Thus, $\mathrm{Tm}^{3+}$ and $\mathrm{Sm}^{3+}$ can substitute $\mathrm{Gd}^{3+}$ and $\mathrm{Ca}^{2+}$ in the initial crystal structure. These data are in good agreement with the occupations of the crystallographic sites. In particular, the octahedral M5 site is occupied by $\mathrm{Tm}^{3+}$ jointly with $\mathrm{Ca}^{2+}$, and the largest M1-M3 sites are statistically occupied by $\mathrm{Gd}^{3+}, \mathrm{Tm}^{3+}, \mathrm{Sm}^{3+}$, and $\mathrm{Ca}^{2+}[20]$. The cationic distribution in $\mathrm{Gd}_{0.9-x} \mathrm{Tm}_{0.1} \mathrm{Sm}_{x}$ and $\mathrm{Gd}_{0.9-y} \mathrm{Tm}_{y} \mathrm{Sm}_{0.1}$ is based on $D_{r}$ calculations. Despite the fact that the $D_{r}$ value of $\mathrm{Ca}^{2+} / \mathrm{Sm}^{3+}$ in the octahedral M5 site is less due to larger 
similarity of the ionic radii, $\mathrm{Tm}^{3+}$ ions are preferably occupied it. The reason is the smaller difference in pair $\mathrm{Ca}^{2+} / \mathrm{Sm}^{3+}\left(D_{r}=3.7\right)$ in comparison with $\mathrm{Ca}^{2+} / \mathrm{Tm}^{3+}\left(D_{r}=13.1\right)$ in larger eight-coordinates sites M1-M3. So, the smallest size of $\mathrm{Tm}^{3+}$ ion is the argument to prefer occupation among other REE ions $\mathrm{Gd}^{3+}$ and $\mathrm{Sm}^{3+}$ in the synthesized compounds.

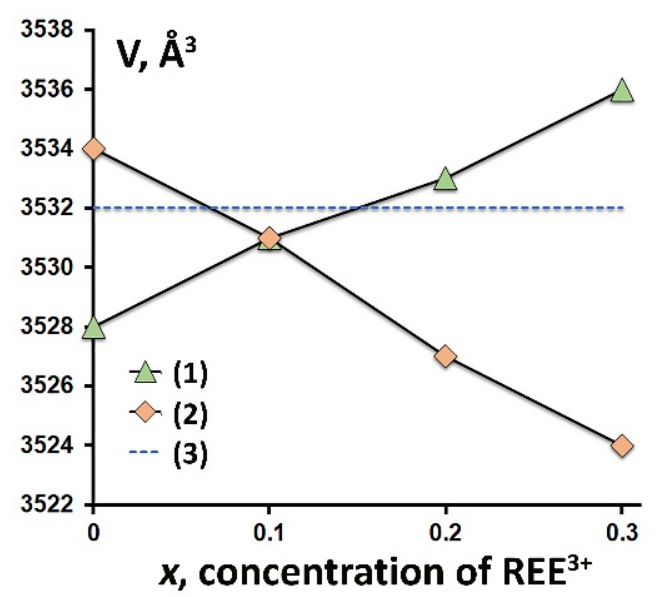

Figure 2. Dependence of the unit cell volumes of $\mathrm{Ca}_{9} \mathrm{Gd}_{0.9-x} \mathrm{Tm}_{0.1} \mathrm{Sm}_{x}\left(\mathrm{PO}_{4}\right)_{7}$ (1) and $\mathrm{Ca}_{9} \mathrm{Gd}_{0.9-y} \mathrm{Tm}_{y} \mathrm{Sm}_{0.1}\left(\mathrm{PO}_{4}\right)_{7}$ (2) on the concentration of REE, and the unit cell volume of pure $\mathrm{Ca} 9 \mathrm{Gd}\left(\mathrm{PO}_{4}\right)_{7}(3)$.

Table 1. The ionic radii difference $D_{r}$ between substituted and dopant ions.

\begin{tabular}{|c|c|c|c|c|c|}
\hline \multirow{3}{*}{ Dopantion } & \multirow{3}{*}{$\begin{array}{c}\text { Radius, } \\
\text { Å/CN }\end{array}$} & \multicolumn{4}{|c|}{$D_{r}, \%$} \\
\hline & & \multicolumn{2}{|c|}{$\mathrm{Gd}^{3+}$} & \multicolumn{2}{|c|}{$\mathrm{Ca}^{2+}$} \\
\hline & & $1.05 \AA ̊ / 8$ & $0.94 \AA ̊ / 6$ & $1.12 \AA ̊ \AA / 8$ & $1.00 \AA ̊ 8$ \\
\hline \multirow{2}{*}{$\operatorname{Tm}^{3+}$} & $0.88 / 6$ & - & 6.8 & - & 13.6 \\
\hline & $0.99 / 8$ & 6.1 & - & 13.1 & - \\
\hline \multirow{2}{*}{$\mathrm{Sm}^{3+}$} & $0.96 / 6$ & - & 1.1 & - & 5.3 \\
\hline & $1.08 / 8$ & 2.7 & - & 3.7 & - \\
\hline
\end{tabular}

Figure 3 shows the SEM image for $\mathrm{Gd}_{0.8} \mathrm{Tm}_{0.1} \mathrm{Sm}_{0.1}$. Observed phosphate, as well as all as-prepared samples, is characterized by narrow size distribution in the interval from 10 to $100 \mu \mathrm{m}$ with a large number of large particles.

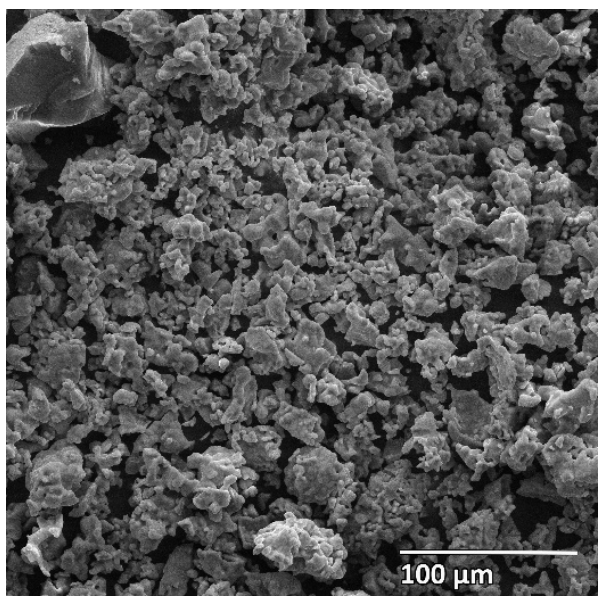

Figure 3. The SEM image for $\mathrm{Ca}_{9} \mathrm{Gd}_{0.8} \mathrm{Tm}_{0.1} \mathrm{Sm}_{0.1}\left(\mathrm{PO}_{4}\right)_{7}$. 
The temperature dependences of dielectric permittivity $(\varepsilon)$ and dielectric loss tangent $(\tan \delta)$ for pure $\mathrm{Ca}_{9} \mathrm{Gd}\left(\mathrm{PO}_{4}\right)_{7}$ are shown in Figure 4 . The maxima at the $\varepsilon(\mathrm{T})$ curves may indicate the phase transition (PT). The presence of anomalies in the tan $\delta$ curves demonstrates the type of PT, which can be determined as ferroelectric type. So, the PT is observed with SG $R 3 c \rightarrow R \overline{3} c$ changing for $\mathrm{Ca}_{9} \mathrm{Gd}\left(\mathrm{PO}_{4}\right)_{7}$. The temperature of $\mathrm{PT}$, determined by maxima and minima in $\varepsilon(\mathrm{T})$ and $\tan \delta(\mathrm{T})$ curves, respectively, takes value of $850 \mathrm{~K}$. The similar behaviors have been also found for $\mathrm{Gd}_{0.9-x} \mathrm{Tm}_{0.1} \mathrm{Sm}_{x}$ and $\mathrm{Gd}_{0.9-y} \mathrm{Tm}_{y} \mathrm{Sm}_{0.1}$ samples. The temperatures of PT vary between $850 \mathrm{~K}$ to $865 \mathrm{~K}$ for as-synthesized phosphates. The obtained data might be considered as equal due to instrumental error $(20 \mathrm{~K})$. The significant changes in PT were not detected with doping by admixture concentration of $\mathrm{Tm}^{3+}$ and $\mathrm{Sm}^{3+}$.

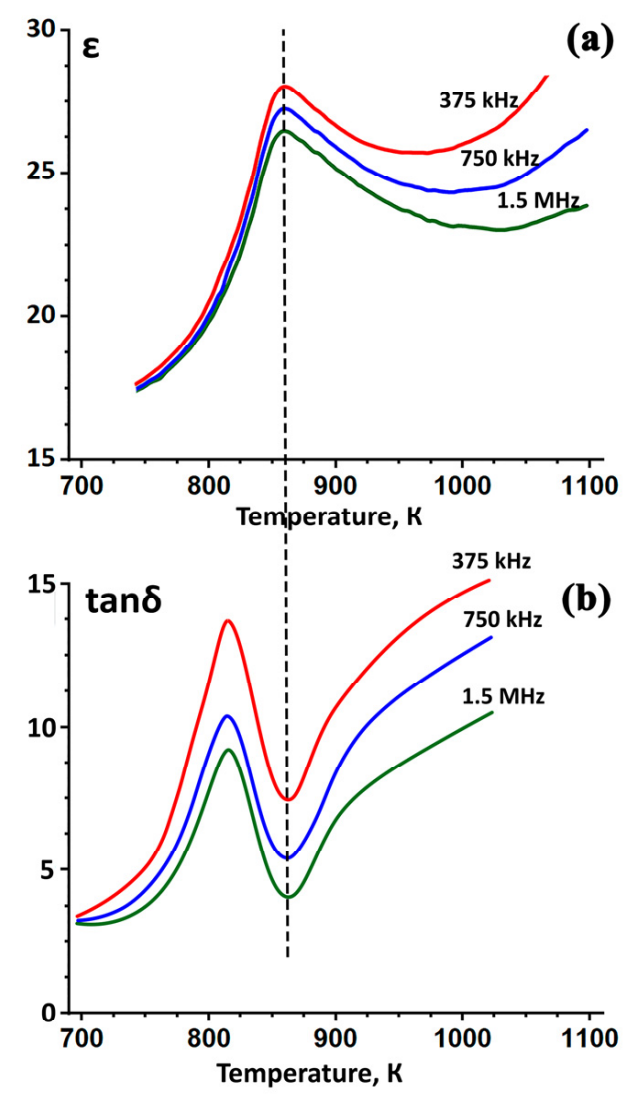

Figure 4. Temperature dependence of the dielectric permittivity $\varepsilon$ (a) and dielectric loss tangent $\tan \delta$ (b) for $\mathrm{Ca} 9 \mathrm{Gd}\left(\mathrm{PO}_{4}\right)_{7}$.

The PLE spectrum of $\mathrm{Gd}_{0.9} \mathrm{Sm}_{0.1}$, recorded at $\lambda_{e m}=602 \mathrm{~nm}$, is given in Figure $5 \mathrm{a}$. The series of sharp lines in the region of 300-500 nm correspond to $f-f$ transitions within $\mathrm{Sm}^{3+}$ ions. The bands at 346, 363, 375, 404, 416, 439, and $475 \mathrm{~nm}$ correspond to $\mathrm{Sm}^{3+}$ transitions from the ${ }^{6} \mathrm{H}_{5 / 2}$ ground level to the excited levels ${ }^{4} \mathrm{H}_{13 / 2},{ }^{4} \mathrm{D}_{3 / 2},{ }^{6} \mathrm{P}_{7 / 2},{ }^{4} \mathrm{~F}_{7 / 2},{ }^{6} \mathrm{P}_{5 / 2},{ }^{4} \mathrm{G}_{9 / 2}$, and ${ }^{4} \mathrm{I}_{11 / 2}$, respectively [22,23]. The most intensive ${ }^{6} \mathrm{H}_{5 / 2} \rightarrow{ }^{4} \mathrm{~F}_{7 / 2}$ transition is located at $404 \mathrm{~nm}$.

At PL spectrum of $\mathrm{Gd}_{0.9} \mathrm{Sm}_{0.1}$, registered at $\lambda_{e x}=404 \mathrm{~nm}$, a standard set of emission lines, which arise due to transitions within $\mathrm{Sm}^{3+}$ ions is observed (Figure $5 \mathrm{~b}$ ). The emission bands in the visible orange-red spectral region peaking at 563, 602, 644 and $704 \mathrm{~nm}$ correspond to ${ }^{4} \mathrm{G}_{5 / 2} \rightarrow{ }^{4} \mathrm{H}_{J / 2}(J=5,7,9,11)$ transitions within $\mathrm{Sm}^{3+}$ ions [22,23]. The dominant line was found at $602 \mathrm{~nm}\left({ }^{4} \mathrm{G}_{5 / 2} \rightarrow{ }^{4} \mathrm{H}_{7 / 2}\right)$. The $4 \mathrm{f}-4 \mathrm{f}$ transitions of $\mathrm{REE}^{3+}$ are almost insensitive to the changing of the crystal field strength, and the profile and relative intensities of the $\mathrm{Sm}^{3+}$ related emission bands were similar for all studied series. The main 
difference between the samples was in the integral emission intensity, which is ascribed to the energy transfer processes.

The PLE spectrum of $\mathrm{Gd}_{0.9} \mathrm{Tm}_{0.1}$, monitored at $\lambda_{\text {em }}=477 \mathrm{~nm}$, is presented in Figure 6a. The spectrum demonstrates an expressed band at $356 \mathrm{~nm}$, corresponding to ${ }^{3} \mathrm{H}_{6} \rightarrow{ }^{1} \mathrm{D}_{2}$ transition within $\mathrm{Tm}^{3+}$. The onset observed below $300 \mathrm{~nm}$ might be attributed to the defectrelated absorption. The characteristic emission line, corresponding to $4 f-4 f$ transition within $\mathrm{Tm}^{3+}$ is observed at PL spectrum (Figure 6b). This band is located at $455 \mathrm{~nm}$ and is due to ${ }^{1} \mathrm{D}_{2} \rightarrow{ }^{3} \mathrm{~F}_{4}$ transition $[14,24,25]$.
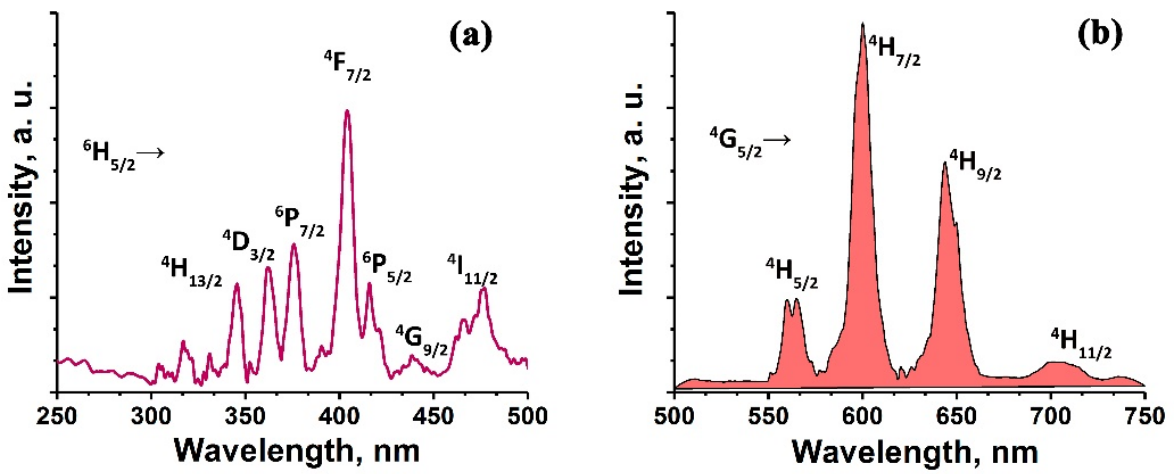

Figure 5. (a) PLE $\left(\lambda_{e m}=602 \mathrm{~nm}\right)$ and (b) PL $\left(\lambda_{e x}=404 \mathrm{~nm}\right)$ spectra for $\mathrm{Ca}_{9} \mathrm{Gd}_{0.9} \mathrm{Sm}_{0.1}\left(\mathrm{PO}_{4}\right)_{7}$.
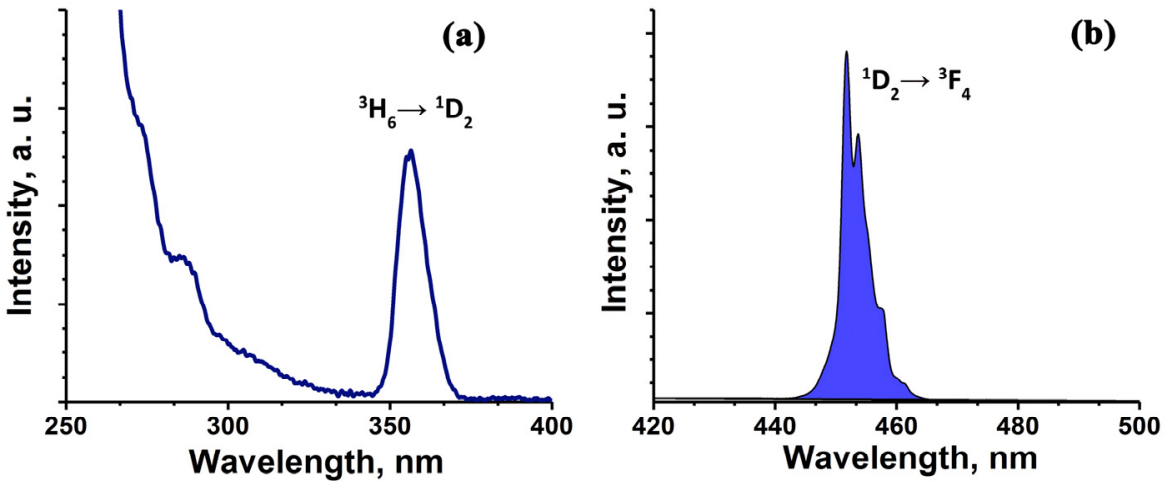

Figure 6. (a) PLE $\left(\lambda_{e m}=477 \mathrm{~nm}\right)$ and $(\mathbf{b}) \operatorname{PL}\left(\lambda_{e x}=356 \mathrm{~nm}\right)$ spectra for $\mathrm{Ca}_{9} \mathrm{Gd}_{0.9} \mathrm{Tm}_{0.1}\left(\mathrm{PO}_{4}\right)_{7}$.

The emission bands of $\mathrm{Tm}^{3+}$ and $\mathrm{Sm}^{3+}$ ions, are registered in PL spectrum of $\mathrm{Gd}_{0.8} \mathrm{Tm}_{0.1} \mathrm{Sm}_{0.1}$ at $\lambda_{e x}=356 \mathrm{~nm}$, which corresponds to intracenter excitation of $\mathrm{Tm}^{3+}$ ions (Figure 7 ). Thus, energy transfer from $\mathrm{Tm}^{3+}$ to $\mathrm{Sm}^{3+}$ occurs. In contrast, energy transfer from $\mathrm{Sm}^{3+}$ to $\mathrm{Tm}^{3+}$ is not registered, which is confirmed by the absence of $\mathrm{Tm}^{3+}$ emission lines under excitation at $\lambda_{\mathrm{ex}}=404 \mathrm{~nm}\left(\mathrm{Sm}^{3+}\right.$ intracenter excitation).

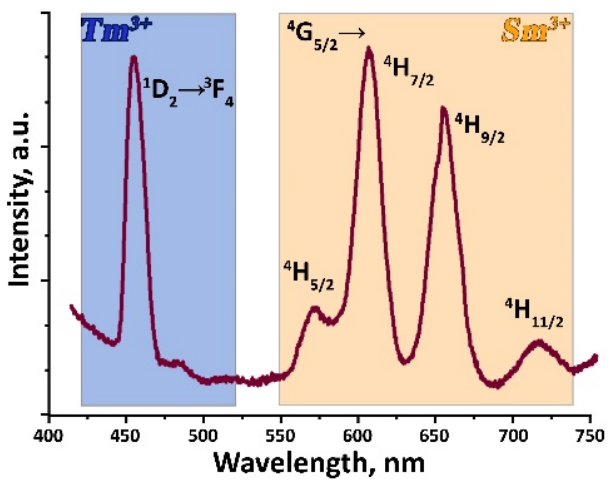

Figure 7. $\mathrm{PL}$ spectrum of $\mathrm{Ca}_{9} \mathrm{Gd}_{0.8} \mathrm{Tm}_{0.1} \mathrm{Sm}_{0.1}\left(\mathrm{PO}_{4}\right)_{7}, \lambda_{\text {ex }}=356 \mathrm{~nm}$. 
The data on the intensity dependence of $\mathrm{Tm}^{3+}$ and $\mathrm{Sm}^{3+}$ emission on the REE concentrations are presented in Figure 8. The intensity of $\mathrm{Sm}^{3+}$ emission for $\mathrm{Gd}_{0.9-x} \operatorname{Tm}_{0.1} \mathrm{Sm}_{x}$ samples increases with $x$. At the same time, the intensity of $\mathrm{Tm}^{3+}$ emission decreases while its concentration doesn't change (Figure 8a). Such behavior indicates the possibility of energy transfer from $\mathrm{Tm}^{3+}$ to $\mathrm{Sm}^{3+}$ under at $356 \mathrm{~nm}$, which correspond to $\mathrm{Tm}^{3+}$ intraceneter excitation. It is worth noting that the intensity of $\mathrm{Sm}^{3+}$ emission is nonzero (Figure $8 \mathrm{~b}$ ) at $\lambda_{e x}=356 \mathrm{~nm}$ even for $\mathrm{Gd}_{0.9} \mathrm{Sm}_{0.1}$, (i.e. without $\mathrm{Tm}^{3+}$ ions in the sample) that is due to the presence of a Sm${ }^{3+}$ excitation band at $356 \mathrm{~nm}$. The increase of the $\mathrm{Sm}^{3+}$ emission is observed with the incorporation of $\mathrm{Tm}^{3+}$ into studied phosphates for the sample $\mathrm{Gd}_{0.8} \mathrm{Tm}_{0.1} \mathrm{Sm}_{0.1}$. The observed intensity increase also indicates the existence of an energy transfer process from $\mathrm{Tm}^{3+}$ to $\mathrm{Sm}^{3+}$. However, the intensity of $\mathrm{Sm}^{3+}$ emission decreases with a further increase of the $\mathrm{Tm}^{3+}$ concentration in the host.

(a)

Integrated Intensity, a.u.

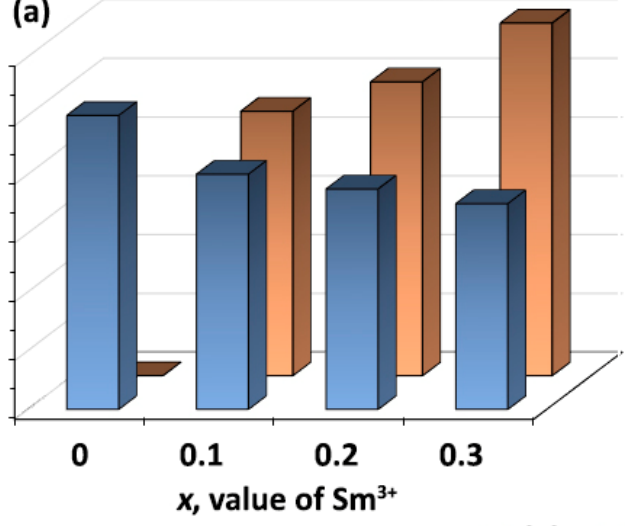

(b)

Integrated Intensity, a.u.

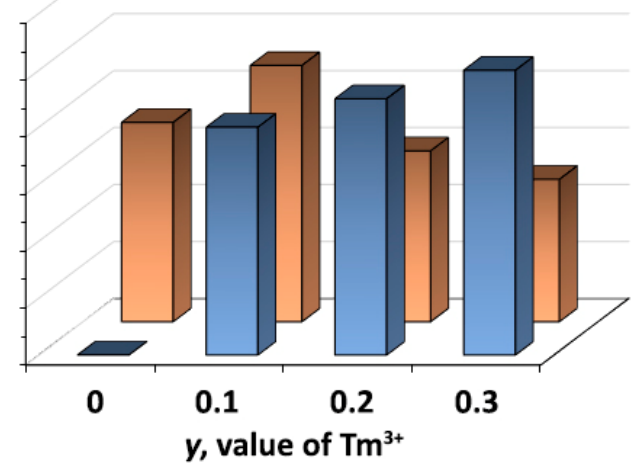

(1)

$\square(2)$

Figure 8. Integrated intensity of $\mathrm{Tm}^{3+}(1)$ and $\mathrm{Sm}^{3+}$ (2) emissions for $\mathrm{Ca}_{9} \mathrm{Gd}_{0.9-x} \mathrm{Tm}_{0.1} \mathrm{Sm}_{x}\left(\mathrm{PO}_{4}\right)_{7}(\mathbf{a})$ and $\mathrm{Ca}_{9} \mathrm{Gd}_{0.9-y} \mathrm{Tm}_{y} \mathrm{Sm}_{0.1}\left(\mathrm{PO}_{4}\right)_{7}(\mathbf{b})$ at $\lambda_{e x}=356 \mathrm{~nm}$.

CIE coordinates $(x, y, z)$ show the color of emission for phosphors, according to international standards. They were calculated using the following equation [26]:

$$
x=\frac{X}{X+Y+Z} ; y=\frac{Y}{X+Y+Z} ; z=\frac{Z}{X+Y+Z} ;
$$

where

$$
X=\int_{\lambda_{\text {inf }}}^{\lambda_{\text {sup }}} S(\lambda) \bar{x}(\lambda) d(\lambda) ; Y=\int_{\lambda_{\text {inf }}}^{\lambda_{\text {sup }}} S(\lambda) \bar{y}(\lambda) d(\lambda) ; Z=\int_{\lambda_{\text {inf }}}^{\lambda_{\text {sup }}} S(\lambda) \bar{z}(\lambda) d(\lambda)
$$

where $S(\lambda)$ is the intensity at wavelength $\lambda ; \bar{x}, \bar{y}, \bar{z}$ are color 1931CIE coordinates (CIE coordinates) at wavelength $\lambda$; $d$ is integration stp.

The calculated color coordinates $(x, y)$ are presented in Figure 9. The CIE value for $\mathrm{Gd}_{0.9} \mathrm{Tm}_{0.1}$ is $(0.17 ; 0.07)$ and corresponds to the blue region of the color space, while $(0.53$; 0.37 ) for $\mathrm{Gd}_{0.9} \mathrm{Sm}_{0.1}$ - to the orange region. The adjusting of $\mathrm{Sm}^{3+}$ concentration shifts the color coordinates from a blue region, through a near white one, to an orange one for $\mathrm{Gd}_{0.9-x} \mathrm{Tm}_{0.1} \mathrm{Sm}_{x}$. This behavior can be explained by the redistribution of $\mathrm{Sm}^{3+}$ and $\mathrm{Tm}^{3+}$ emission bands intensity under $\lambda_{e x}=356 \mathrm{~nm}$. 


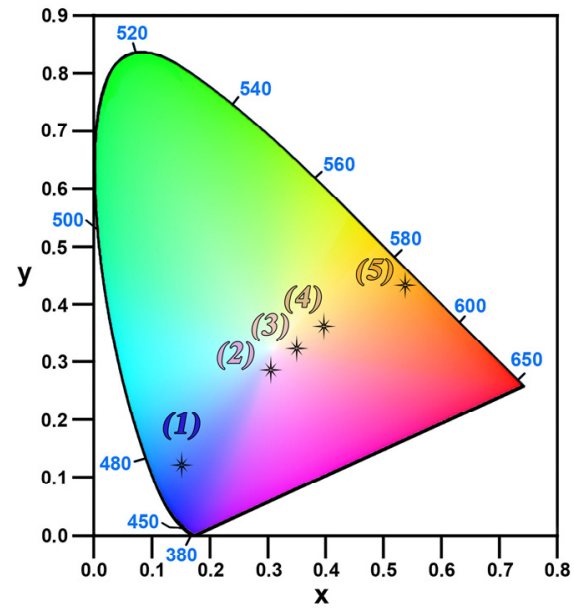

Figure 9. Color coordinates for $\mathrm{Ca}_{9} \mathrm{Gd}_{0.9-x} \mathrm{Tm}_{0.1} \mathrm{Sm}_{x}\left(\mathrm{PO}_{4}\right)_{7} x=0$ (1), $x=0.1$ (2), $x=0.2$ (3), $x=0.3(4)$ and $\mathrm{Ca}_{9} \mathrm{Gd}_{0.9} \mathrm{Sm}_{0.1}\left(\mathrm{PO}_{4}\right)_{7}(5)$.

\section{Conclusions}

Novel Ca9 $\mathrm{Gd}_{0.9-x} \mathrm{Tm}_{0.1} \mathrm{Sm}_{x}\left(\mathrm{PO}_{4}\right)_{7}(x=0 ; 0.1 ; 0.2 ; 0.3)$ and $\mathrm{Ca}_{9} \mathrm{Gd}_{0.9-y} \mathrm{Tm}_{y} \mathrm{Sm}_{0.1}\left(\mathrm{PO}_{4}\right)_{7}$ $(y=0 ; 0.1 ; 0.2 ; 0.3)$ phosphates with $\beta$ - $\mathrm{Ca}_{3}\left(\mathrm{PO}_{4}\right)_{2}$-type structure were synthesized by a solidstate technique. It was found that the admixture concentration of REE ions in the initial host does not influence on the formation of the whitlockite-type structure and dielectric properties. The temperature of phase transitions is $850-865 \mathrm{~K}$ for as-prepared samples. The REE emitting-ions can be exctied by ultraviolet radiation being in admixture quantity in the whitlockite-type host. The typical emissions in the orange (the most intensive band at $602 \mathrm{~nm}$ ) and the blue (the most intensive band at $455 \mathrm{~nm}$ ) spectral regions were observed for $\mathrm{Ca}_{9} \mathrm{Gd}_{0.9} \mathrm{Sm}_{0.1}\left(\mathrm{PO}_{4}\right)_{7}$ and $\mathrm{Ca}_{9} \mathrm{Gd}_{0.9} \mathrm{Tm}_{0.1}\left(\mathrm{PO}_{4}\right)_{7}$, respectively. The energy transfer from $\mathrm{Tm}^{3+}$ to $\mathrm{Sm}^{3+}$ was detected for $\mathrm{Ca}_{9} \mathrm{Gd}_{0.9-y} \mathrm{Tm}_{y} \mathrm{Sm}_{0.1}\left(\mathrm{PO}_{4}\right)_{7}$ solid solution. It is shown that the resulting emission in the near-white area of $\mathrm{CIE}$ coordinates can be achieved by tuning of $\mathrm{Sm}^{3+}$ concentration in the $\mathrm{Ca}_{9} \mathrm{Gd}_{0.9-x} \mathrm{Tm}_{0.1} \mathrm{Sm}_{x}\left(\mathrm{PO}_{4}\right)_{7}$ solid solutions.

Author Contributions: Conceptualization, I.V.N., D.A.S. and D.V.D.; methodology, D.V.D. and S.M.A.; synthesis, I.V.N.; formal analysis, I.V.N., D.V.D. and D.A.S.; writing-original draft preparation, I.V.N. and D.V.D.; writing-review and editing, B.I.L., D.A.S. and S.M.A.; supervision, D.V.D. All authors have read and agreed to the published version of the manuscript.

Funding: This research was supported by the Russian Science Foundation (Grant 19-77-10013). D.A.S. is grateful for financial support of the Estonian Research Council, project PUT PRG111. This research was performed according to the Development Program of the Interdisciplinary Scientific and Educational School of Lomonosov Moscow State University's "The future of the planet and global environmental change" and the state assignment of the Chemistry Department of Moscow State University (Agreement No. AAAA-A21-121011590086-0).

Conflicts of Interest: The authors declare no conflict of interest.

\section{References}

1. Teterskii, A.V.; Stefanovich, S.Y.; Lazoryak, B.I.; Rusakov, D.A. Whitlockite solid solutions $\mathrm{Ca}_{9-\mathrm{x}} \mathrm{M}_{\mathrm{x}} \mathrm{R}\left(\mathrm{PO}_{4}\right)_{7}(\mathrm{x}=1,1.5 ; \mathrm{M}=\mathrm{Mg}$, Zn, Cd; R = Ln, Y) with antiferroelectric properties. Russ. J. Inorg. Chem. 2007, 52, 308-314. [CrossRef]

2. Deyneko, D.V.; Aksenov, S.M.; Nikiforov, I.V.; Stefanovich, S.Y.; Lazoryak, B.I. Symmetry inhomogeneity of $\mathrm{Ca}_{-\mathrm{x}} \mathrm{Zn}_{\mathrm{x}} \mathrm{Eu}\left(\mathrm{PO}_{4}\right)_{7}$ phosphor determined by second-harmonic generation and dielectric and photoluminescence spectroscopy. Cryst. Growth Des. 2020, 20, 6461-6468. [CrossRef]

3. Nikiforov, I.V.; Deyneko, D.V.; Duskaev, I.F.; Lazoryak, B.I. Green luminophors in the family of phosphates with whitlockite structure. J. Struct. Chem. 2021, 62, 1621-1630. [CrossRef]

4. Lazoryak, B.I.; Zhukovskaya, E.S.; Baryshnikova, O.V.; Belik, A.A.; Leonidova, O.N.; Deyneko, D.V.; Savon, A.E.; Dorbakov, N.G.; Morozov, V.A. Luminescence, structure and antiferroelectric-type phase transition in $\mathrm{Ca}_{8} \mathrm{ZnEu}\left(\mathrm{PO}_{4}\right)_{7}$. Mater. Res. Bull. 2018, 104, 20-26. [CrossRef] 
5. Deyneko, D.V.; Morozov, V.A.; Hadermann, J.; Savon, A.E.; Spassky, D.A.; Stefanovich, S.Y.; Belik, A.A.; Lazoryak, B.I. A novel red $\mathrm{Ca}_{8.5} \mathrm{~Pb}_{0.5} \mathrm{Eu}\left(\mathrm{PO}_{4}\right)_{7}$ phosphor for light emitting diodes application. J. Alloy. Compd. 2015, 647, 965-972. [CrossRef]

6. Deyneko, D.V.; Nikiforov, I.; Lazoryak, B.I.; Spassky, D.A.; Leonidov, I.I.; Stefanovich, S.Y.; Petrova, D.A.; Aksenov, S.M.; Burns, P.C. $\mathrm{Ca}_{8} \mathrm{MgSm}_{1-x}\left(\mathrm{PO}_{4}\right)_{7}: \mathrm{xEu}^{3+}$, promising red phosphors for WLED application. J. Alloy. Compd. 2019, 776, 897-903. [CrossRef]

7. Deyneko, D.V.; Spassky, D.A.; Morozov, V.A.; Aksenov, S.M.; Kubrin, S.P.; Molokeev, M.S.; Lazoryak, B.I. Role of the Eu ${ }^{3+}$ distribution on the properties of $\beta-\mathrm{Ca}_{3}\left(\mathrm{PO}_{4}\right)_{2}$ phosphors: Structural, luminescent, and 151Eu Mössbauer spectroscopy study of $\mathrm{Ca}_{9.5-1.5 x} \mathrm{MgEu}_{\mathrm{x}}\left(\mathrm{PO}_{4}\right)_{7}$. Inorg. Chem. 2021, 60, 3961-3971. [CrossRef]

8. Xie, F.; Xu, D.; Wu, Z.; Molokeev, M.S.; Milićević, B.; Li, H.; Shi, J. Improving thermal stability of novel single-component

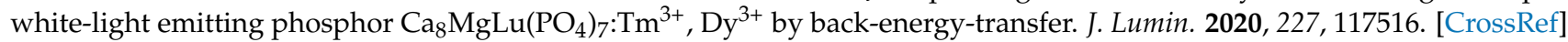

9. Zhang, J.; Wang, Y.; Guo, L.; Zhang, F.; Wen, Y.; Liu, B.; Huang, Y. Vacuum ultraviolet and near-infrared excited luminescence properties of $\mathrm{Ca}_{3}\left(\mathrm{PO}_{4}\right)_{2}: \mathrm{RE}^{3+}, \mathrm{Na}^{+}(\mathrm{RE}=\mathrm{Tb}, \mathrm{Yb}, \mathrm{Er}, \mathrm{Tm}$, and Ho). J. Solid State Chem. 2011, 184, 2178-2183. [CrossRef]

10. Zhang, Z.-W.; Wu, Y.-N.; Shen, X.-H.; Ren, Y.-J.; Zhang, W.-G.; Wang, D.-J. Enhanced novel orange red emission in $\mathrm{Ca}_{3}\left(\mathrm{PO}_{4}\right)_{2}$ $\mathrm{Sm}^{3+}$ by charge compensation. Opt. Laser Technol. 2014, 62, 63-68. [CrossRef]

11. Xie, M.; Liang, H.; Huang, Y.; Gao, Z.; Tao, Y. Host absorption sensitizing and energy transfer to Eu ${ }^{3+}$ by Gd $\mathrm{G}^{3+}$ in $\mathrm{Ba}_{6} \mathrm{Gd}_{2-\mathrm{x}} \mathrm{Na}_{2} \mathrm{Eu}_{x}\left(\mathrm{PO}_{4}\right)_{6} \mathrm{~F}_{2}$. J. Solid State Chem. 2013, 201, 18-23. [CrossRef]

12. Guo, N.; Liang, Q.; Li, S.; Ouyang, R.; Lü, W. Triple energy transfer and color tuning in $\mathrm{Tb}^{3+}$ and Eu ${ }^{3+}$-coactivated apatite-type gadolinium-containing phosphors. Opt. Mater. 2017, 73, 570-576. [CrossRef]

13. Paszkowicz, W.; Shekhovtsov, A.; Kosmyna, M.; Loiko, P.; Vilejshikova, E.; Minikayev, R.; Romanowski, P.; Wierzchowski, W.; Wieteska, K.; Paulmann, C.; et al. Structure and thermal expansion of $\mathrm{Ca}_{9} \mathrm{Gd}\left(\mathrm{VO}_{4}\right)_{7}$ : A combined powder-diffraction and dilatometric study of a Czochralski-grown crystal. Nucl. Instrum. Methods Phys. Res. Sect. B Beam Interact. Mater. At. 2017, 411, 100-111. [CrossRef]

14. Liu, X.; Li, L.; Noh, H.M.; Jeong, J.H.; Jang, K.; Shin, D.S. Chemical bond parameters, charge transfer band, tunable white light of $\mathrm{Tm}^{3+}$ and $\mathrm{Sm}^{3+}$ coactivated Ca9 $\mathrm{Gd}\left(\mathrm{VO}_{4}\right)_{7}$. J. Alloy. Compd. 2015, 618, 649-655. [CrossRef]

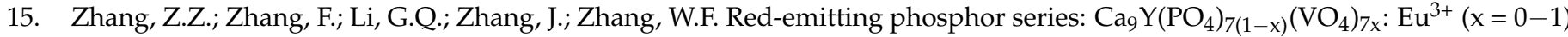
with improved luminescence thermal stability by anionic polyhedron substitution. J. Mater. Sci. Mater. Electron. 2019, 30, 8838-8846. [CrossRef]

16. Petříček, V.; Dušek, M.; Palatinus, L. Crystallographic computing system JANA2006: General features. Z. Krist. Cryst. Mater. 2014, 229, 345-352. [CrossRef]

17. Deyneko, D.V.; Nikiforov, I.V.; Spassky, D.A.; Berdonosov, P.S.; Dzhevakov, P.B.; Lazoryak, B.I. $\mathrm{Sr}_{8} \mathrm{MSm}_{1-\mathrm{x}} \mathrm{Eu}_{\mathrm{x}}\left(\mathrm{PO}_{4}\right)_{7}$ phosphors derived by different synthesis routes: Solid state, sol-gel and hydrothermal, the comparison of properties. J. Alloy. Compd. 2021, 887, 161340. [CrossRef]

18. Dikhtyar, Y.Y.; Deyneko, D.V.; Boldyrev, K.N.; Borovikova, E.Y.; Lipatiev, A.S.; Stefanovich, S.Y.; Lazoryak, B.I. Luminescent properties of $\mathrm{Er}^{3+}$ in centrosymmetric and acentric phosphates $\mathrm{Ca}_{8} \mathrm{MEr}\left(\mathrm{PO}_{4}\right)_{7}(\mathrm{M}=\mathrm{Ca}, \mathrm{Mg}, \mathrm{Zn})$ and $\mathrm{Ca}_{-} \mathrm{Zn}_{\mathrm{x}} \mathrm{La}_{(}\left(\mathrm{PO}_{4}\right)_{7}: \mathrm{Er}^{3+}$. Mater. Res. Bull. 2021, 138, 111244. [CrossRef]

19. Deyneko, D.V.; Nikiforov, I.; Spassky, D.; Dikhtyar, Y.Y.; Aksenov, S.M.; Stefanovich, S.Y.; Lazoryak, B.I. Luminescence of Eu ${ }^{3+}$ as a probe for the determination of the local site symmetry in $\beta-\mathrm{Ca}_{3}\left(\mathrm{PO}_{4}\right)_{2}$-related structures. CrystEngComm 2019, 21, 5235-5242. [CrossRef]

20. Bessière, A.; Benhamou, R.A.; Wallez, G.; Lecointre, A.; Viana, B. Site occupancy and mechanisms of thermally stimulated luminescence in $\mathrm{Ca}_{9} \mathrm{Ln}\left(\mathrm{PO}_{4}\right)_{7}$ (Ln=lanthanide). Acta Mater. 2012, 60, 6641-6649. [CrossRef]

21. Shannon, R. Revised effective ionic radii and systematic study of inter atomic distances in halides and chalcogenides. Acta Crystallogr. Sect. A Found. Crystallogr. 1976, 32, 751-767.

22. Zhang, Z.-J.; Yang, W. Luminescence characteristic of RE (RE = Pr, Sm, Eu, Tb, Dy) and energy levels of lanthanide ions in $\mathrm{Gd}_{5} \mathrm{Si}_{3} \mathrm{O}_{12} \mathrm{~N}$. Solid State Sci. 2017, 72, 64-70. [CrossRef]

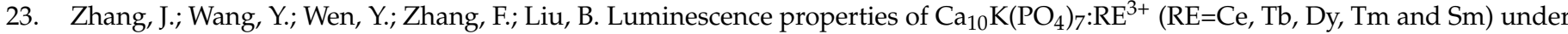
vacuum ultraviolet excitation. J. Alloy. Compd. 2011, 509, 4649-4652. [CrossRef]

24. Gruber, J.B.; Conway, J.G. Electronic energy levels and crystal quantum states of Tm (IV). J. Chem. Phys. 1960, 32, 1178. [CrossRef]

25. Baklanova, Y.V.; Lipina, O.A.; Surat, L.L.; Chufarov, A.Y.; Tyutyunnik, A.P.; Zubkov, V.G. Luminescence Properties of $\mathrm{Sr}_{2} \mathrm{La}_{8-x} \mathrm{Tm}_{x}\left(\mathrm{GeO}_{4}\right)_{6} \mathrm{O}_{2}$ Apatites $(x=0.1-1.0)$ in the Visible and Short-Wave IR Spectral Ranges. Phys. Solid State 2020, 62, 1407-1414. [CrossRef]

26. Ferhi, M.; Horchani-Naifer, K.; Férid, M. Spectroscopic properties of Eu ${ }^{3+}$-doped $\mathrm{KLa}\left(\mathrm{PO}_{3}\right)_{4}$ and $\mathrm{LiLa}\left(\mathrm{PO}_{3}\right)_{4}$ powders. Opt. Mater. 2011, 34, 12-18. [CrossRef] 